\title{
A ROLE FOR ARCHAEAL ORGANISMS IN DEVELOPMENT OF ATHEROSCLEROTIC VULNERABLE PLAQUES AND MYXOID MATRICES
}

\author{
Maria L Higuchi, Marilia H Santos, Alessandra Roggério, Joyce T Kawakami, \\ Hiram G Bezerra, Mauro Canzian
}

\begin{abstract}
Higuchi ML, Santos MH, Roggério A, Kawakami JT, Bezerra HG, Canzian M. A role for archaeal organisms in development of atherosclerotic vulnerable plaques and myxoid matrices. CLINICS. 2006;61(5):473-8.
\end{abstract}

PURPOSE: Vulnerable plaques are characterized by a myxoid matrix, necrotic lipidic core, reactive oxygen species, and high levels of microorganisms. Aerobic microbes such as Chlamydophila pneumoniae and Mycoplasma pneumoniae usually do not survive in oxidative stress media. Archaea are anaerobic microbes with powerful anti-oxidative enzymes that allow detoxification of free radicals whose presence might favor the survival of aerobic microorganisms. We searched for archaeal organisms in vulnerable plaques, and possible associations with myxoid matrix, chlamydia, and mycoplasma bodies.

METHODS: Twenty-nine tissue samples from 13 coronary artherectomies from large excentric ostial or bifurcational lesions were studied using optical and electron microscopy. Infectious agents compatible with archaea, chlamydia, and mycoplasma were semiquantified using electron micrographs and correlated with the amounts of fibromuscular tissue, myxoid matrix, and foam cells, as determined from semi-thin sections. Six of the cases were also submitted to polymerase chain reaction with archaeal primers.

RESULTS: All 13 specimens showed archaeal-compatible structures and chlamydial and mycoplasmal bodies in at least 1 sample. There was a positive correlation between extent of the of myxoid matrix and archaeal bodies $(\mathrm{r}=0.44, P=0.02)$; between archaeal and mycoplasmal bodies $(\mathrm{r}=0.41, P=0.03)$, and between chlamydial bodies and foam cells $(\mathrm{r}=0.42 ; P=0.03)$. The PCR test was positive for archaeal DNA in 4 of the 6 fragments.

DISCUSSION: DNA and forms suggestive of archaea are present in vulnerable plaques and may have a fundamental role in the proliferation of mycoplasma and chlamydia. This seems to be the first description of apparently pathogenic archaea in human internal organ lesions.

KEYWORDS: Archaea. Atherosclerosis. Myxoid matrix. Chlamydia pneumoniae. Mycoplasma pneumoniae.

\section{INTRODUCTION}

Vulnerable plaques are rich in foam cells, ${ }^{1}$ necrotic lipid tissue, oxidized LDL (oxLDL), ${ }^{2}$ and inflammation. ${ }^{3,4}$ The presence of oxLDL has been related to the inflammation at the subendothelial space $^{5}$ where microaggregated LDL is internalized by macrophages and smooth muscle cells forming the foam cells. ${ }^{6,7}$ Native LDL is considered

Heart Institute (InCor), Hospital das Clínicas, São Paulo University Medical School São Paulo/SP, Brazil.

Email: anplourdes@incor.usp.br

Received for publication on June 26, 2006

Accepted for publication on August 7, 2006. nonatherogenic, but the presence of metals and reactive oxygen species (ROS) modifies the LDL resulting in oxLDL, which is quickly internalized by macrophages ${ }^{8,9}$ that become chemoattractive for monocytes and $\mathrm{T}$ lymphocytes, which stimulates smooth cell proliferation and induces production of autoantibodies and immune complexes that facilitate LDL internalization by macrophages. The recruitment of inflammatory cells may result in continued oxidation of LDL and maintenance of the atherosclerotic lesion process. ${ }^{10}$

Infectious agents have been frequently detected in coronary atheromas, mainly Chlamydophila pneumoniae $(\mathrm{CP})^{11-13}$ with controversial interpretations; ${ }^{14-16}$ Helicobacter pylori, 
Escherichia coli, and cytomegalovirus have been occasionally associated with cardiovascular events. ${ }^{17}$ Co-infections have also been described, for example, with Mycoplasma pneumoniae (MP) and $\mathrm{CP}$, which have been detected in coronary vulnerable plaques ${ }^{18,19}$ and in calcified foci of stenotic aortic valves in elderly patients. ${ }^{20,21}$ Multiple co-infections by mycoplasma, chlamydia, and viruses have been described in patients with chronic diseases, ${ }^{22}$ and a higher prevalence of seropositivity for MP was observed in coronary artery disease of patients seropositive for $\mathrm{CP}^{23}$ Therefore, the question arises as to whether infectious agents might be related to the development of ROS and oxLDL. Chlamydophila pneumoniae has already been related to the LDL oxidation process. ${ }^{24}$ Although CP and MP have been found in large amounts in vulnerable atherosclerotic plaques, they have also been detected in lower quantities in nonatherosclerotic vessels, suggesting that a co-factor could be determining their proliferation. ${ }^{25}$

It is intriguing to ponder that since vulnerable plaque is a rich ROS media, how is it that chlamydia, mycoplasma, and other microorganisms may exhibit greater proliferation at those sites? Relatively low steady-state levels of intracellular superoxide or $\mathrm{H}_{2} \mathrm{O}_{2}$ causes oxidative stress-defined as an imbalance between oxidants and antioxidants in favor of the oxidants, potentially leading to damage ${ }^{26}$ with reduction in the growth of aerobic or anaerobic bacteria. ${ }^{27}$

Superoxide dismutases (SOD) play an essential role in the defense against oxygen toxicity and have been found in the cytosol of anaerobic microorganisms, including archaeal representatives. ${ }^{28}$ Archaea occupy the deepest and shortest branches of the universal phylogenetic tree. ${ }^{29}$ One of their most particular characteristics is the ability to oxidize hydrogen and reduce metals such as $\mathrm{Fe}$ and $\mathrm{Mn} .^{30,31}$ The presence of SOD in archaea is a significant finding, as they exhibit unique properties of stability to extreme conditions.

In the present work, we explored whether archaeal organisms may be participating in the pathogenesis of atherosclerotic plaque vulnerability and proliferation of other infectious agents such as mycoplasma and chlamydia.

\section{METHODS}

This work was performed in patients, most of them with symptoms of unstable angina, undergoing interventional pre-stenting directional coronary atherectomy in ostial or bifurcational excentric atherosclerotic plaques at the Heart Institute (InCor), Hospital das Clínicas, São Paulo, University Medical School, after approval by the Ethical and Scientific Committee. Two or 3 fragments were obtained from each of 13 patients (10 men and 3 women, mean age, 64 +/- 12 years and $69+/-12$ years, respectively, with a total of 29 fragments being studied. The specimens were fixed in $2 \%$ glutaraldehyde, processed to be embedded in araldite, and submitted to semi-thin and thin sectioning, which were analyzed by optical and transmission electron microscopy, respectively. In 6 of the 13 cases, samples were frozen in $-70^{\circ} \mathrm{C}$ liquid nitrogen for polymerase chain reaction (PCR) studies.

Semi-thin sections were analyzed by optical microscopy. The variables, fibromuscular tissue, lipidic core, myxoid matrix (MM), and foam cells, were semiquantified as follows: absent $(0)$, less than $5 \%(1+)$, less than $25 \%(2+)$, or more than $25 \%(3+)$ of the sample. Infectious agents bodies compatible with archaea, chlamydia, and mycoplasma were semiquantified from 5 representative electron micrographs, magnified 15,000 times, as absent (0), scarce (1+), moderate $(2+)$, or severe $(3+)$. Detailed aspects of the microorganisms were observed at 90,000 times magnification. The fragments were subdivided into 2 groups, without or with some area of myxoid matrix, which is indicative of plaque instability. These groups were compared regarding the frequency of archaeal elements.

\section{Tissue preparation for optical and transmission electron microscopy}

Tissue fragments less than $0.1 \mathrm{~cm}$ thickness were fixed in $2 \%$ glutaraldehyde for 2 hours, postfixed in $1 \%$ osmium tetroxide, dehydrated, and embedded in araldite resin. Semi-thin sections (0.5 um. thickness) were stained with toluidine blue, and ultrathin sections (70 $\mathrm{nm}$ thickness) were stained with uranyl acetate and lead citrate.

\section{Polymerase chain reaction (PCR) technique}

DNA from the frozen tissues was obtained using the Dneasy Tissue kit (QIAGEN) following manufactor instructions. PCR was performed using $20 \mathrm{mM}$ Tris- $\mathrm{HCl}(\mathrm{pH} \mathrm{8.4)}$, $50 \mathrm{mM} \mathrm{KCl}, 2.0 \mathrm{mM} \mathrm{MgCl}, 200 \mathrm{mM}$ of each dNTP, 1.0 pmol of each primer (1100F: 5'AGTCAGGTAACGAGCGAG- 3'; 1400R: 5' GTGCAAGGAGCAGGGAC-3'), 2.5 U of Platinum Taq DNA Polymerase (Invitrogen), and $5 \mathrm{~mL}$ of DNA, in a final volume final of $25 \mathrm{ml}$. The amplification was carried out with a PTC - 100 (MJResearch, Inc) thermocycler, using the following program: $95^{\circ} \mathrm{C}$ for 10 minutes, followed by 40 cycles at $95^{\circ} \mathrm{C}$ for $60 \mathrm{~s}, 55^{\circ} \mathrm{C}$ for 1 minute and $30 \mathrm{~s}$, $72^{\circ} \mathrm{C}$ for $60 \mathrm{~s}$, and $72^{\circ} \mathrm{C}$ for 10 minutes. The reaction was analyzed on $2 \%$ agarose stained with ethidium bromide, with ultraviolet (UV) transillumination. As a positive con- 
trol, we used a culture of Halobacterium salinarum (positive reaction at $300 \mathrm{pb}$ ), kindly provided by Prof. Maysa Beatriz Mandetta Clementino, from the Bacteria and Archaea Reference Section of Microbiology Department, National Institute of Quality Control in Health, Oswaldo Cruz Foundation - FIOCRUZ, Rio de Janeiro.

\section{Statistical analysis}

The Spearman correlation test was used to test the number of infectious agent bodies from electron microscopy versus the histological aspects of plaque vulnerability. The Student $t$ test was used to identify a possible association between archaeal elements and myxoid matrix and other infectious agents, ie, mycoplasmal and chlamydial bodies.

\section{RESULTS}

Electron microscopy revealed numerous elements compatible with archaea, i.e., rounded elements showing dimensional variation, surrounded by an irregular folded monolipid membrane, which frequently presented invaginations forming large rounded and flattened vesicles into a homogeneous clear cytoplasmic material. The morphology of these elements varied according to the section axis. (Figure 1).

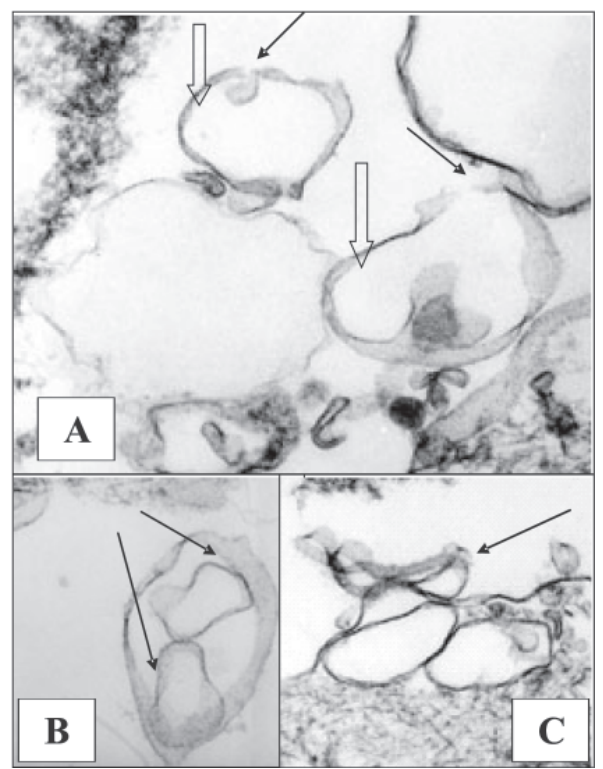

Figure 1 - Electron micrograph exhibiting rounded and flattened bodies suggestive of archaeal origin sectioned in different positions: 1A) 2 elements transversally sectioned enveloped by a monolayer lipid membrane that invaginates (arrows) forming large, clear intracytoplasmic vacuoles (empty arrows). 1B) Close view of an archaeal-suggestive element sectioned at the level of folded external membrane entrances (arrows) 1C) Close view of an archaeal-suggestive element sectioned on the sagittal axis, revealing a flattened and folded aspect (arrow). 10000x original magnification
The archaeal elements were frequently seen in close contact with chlamydial elementary bodies, which have a typical form, i.e., round dark structures enclosed by a double membrane with an small expansion that gives the characteristic pear shape to $C$. pneumoniae; alternatively, they were frequently seen with mycoplasmal forms characterized by rounded elements with granulous cytoplasmic material enclosed by a unique membrane (Figure 2A).

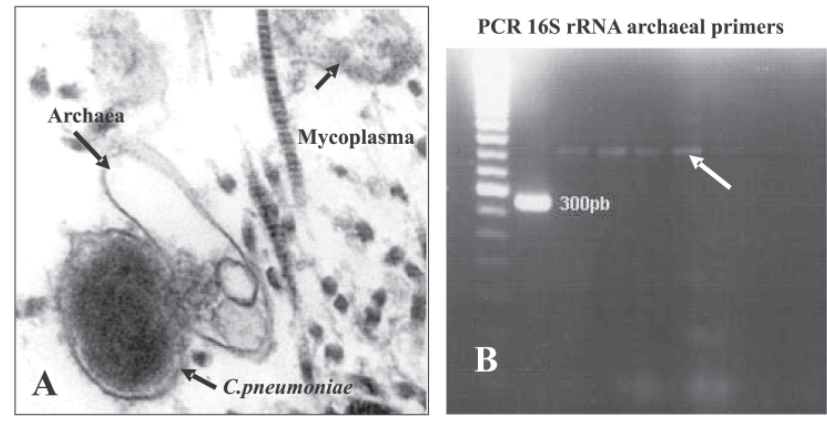

Figure 2 - A) Electron micrograph of a vulnerable plaque exhibiting a Chlamydophila pneumoniae elementary body in close contact with an archaeal-suggestive element, which contains intracytoplasmic vacuoles. A mycoplasmal element is also present. 2B) PCR test for archaeal DNA was positive in 4 of the 6 cases (arrow points to the 400 bp product; left channel is the positive control).

The PCR test for archaeal DNA was positive in 4 of the 6 cases. Figure 2B shows the PCR results, the first sample being the positive control. Our samples showed a constant positive reaction at $400 \mathrm{pb}$, using the same $1.110 \mathrm{~F}$ and $1.400 \mathrm{R}$ generic archaeal primers that show positivity in the control at $300 \mathrm{pb}$. We divided the analyzed fragments into 2 groups, MM-negative samples and MM-positive samples. The semiquantitative analysis showed a significantly higher amount of archaeal-suggestive bodies and lipidic necrotic core in the MM-positive group than in the MMnegative group, with no difference regarding mycoplasmal and chlamydial bodies (Table 1). Considering all fragments, positive correlations were observed between extent of MM regions and the amount of archaeal-suggestive bodies $(r=$ $0.44, P=0.02)$; archaeal and mycoplasmal bodies $(\mathrm{r}=0.41$, $P=0.03)$, and chlamydial bodies and foam cells $(\mathrm{r}=0.42$; $P=0.03)$.

\section{DISCUSSION}

Atherosclerosis has different characteristics among individuals and among areas in a same individual and is related to oxidative LDL. ${ }^{32}$ How infectious agents may participate in the pathogenesis of different atherosclerotic vulnerability is our focus in this work. Chlamydophila pneumoniae has been related to the LDL oxidation process, ${ }^{23}$ and previously we have identified LDL particles in 
Table 1 - Mean and standard deviation of semiquantitative results

\begin{tabular}{lcccccc}
\hline Group & Lipid core & FM & MM & Foam cell & archaea & CP \\
\hline MM neg $(\mathrm{n}=14)$ & $0.57 \pm 0.76$ & $2.5 \pm 1.09$ & $0 \pm 0$ & $0.86 \pm 1.10$ & $0.5 \pm 0.76$ & $1.85 \pm 0.99$ \\
MM pos $(\mathrm{n}=15)$ & $2.2 \pm 0.77$ & $1.4 \pm 1.35$ & $2.13 \pm 0.83$ & $0.93 \pm 1.16$ & $1.29 \pm 0.82$ & $1.5 \pm 1.02$ \\
$t$ test $(P)$ & $<0.001$ & 0.012 & $<0.001$ & 0.43 & $0.93 \pm 007$ & 0.19 \\
\hline
\end{tabular}

MM neg - group of blocks negative for myxoid matrix, evaluated in semi-thin sections

MM pos - group of blocks positive for myxoid matrix. FM - fibromuscular tissue

$\mathrm{CP}$ - Chlamydophila pneumoniae

the serum of atherosclerotic elderly patients with antigens of MP in association with C-reactive protein. ${ }^{33}$ Archaea is a highly diverse and abundant group of prokaryotes, including a number of extremophiles that thrive in hostile environments such as hot springs, salt lakes, submarine volcanic habitats, in addition to more physiological sites. ${ }^{34}$ Despite being one of the most numerous and ubiquitous life forms on earth, the domain Archaea is generally assumed not to cause human disease. ${ }^{35-37}$ They have been described in luminal intestinal microbial ecosystems producing methane, having $\mathrm{CO}_{2}$ as the main carbon substrate. ${ }^{38}$ Genomes of archaea have been described in persistent pathogens and it is suggested that they may confer metabolic capabilities as adaptational strategies for survival even in hostile host niches by breaching host barriers that exclude other organisms. ${ }^{39}$ Recently, genetic sequences of members of domain archaea were found in necrotic material from apical periodontitis, suggesting that archaea may play a role as a human pathogen..$^{40}$ In the present study we detected archaea sugestive microorganisms in human atherosclerotic lesions.

We analyzed atheroma-vulnerable tissues obtained from interventional atherotomy procedures and identified $16 \mathrm{~S}$ rRNA archaeal genomic sequences by PCR assay in 4 of the 6 cases analyzed. Usually, archaeal sequences exhibit $300 \mathrm{pb}$ in PCR technique, as indicated by our positive control of a cultive from $H$. sulpholobus. However, our cases showed a constant positivity at $400 \mathrm{pb}$, with the same sequences of archaeal primers, suggesting a different size of archaeal DNA.

Archaeal morphology has not been very well described, and the rare ultrastructural descriptions were of archaea from artificial cultures. ${ }^{41}$ In our cases, transmission electron microscopy exhibited numerous structures compatible with archaea in $100 \%$ of the cases. Archaea have a unique phospholipid membrane that can be structurally modified, allowing adaptation to high temperatures and high salinity; it is quite differently composed compared to a bacterial membrane..$^{42}$ So it is reasonable to suppose that changes in the morphology, lipid composition, and fluidity of archaeal membranes occur according to the environmental needs. ${ }^{43}$ The archaeal-compatible bodies present at the vulnerable plaques were characterized by roundness and contained large clear intracytoplasmic vacuoles that might have contained gases. Although the membrane-related processes in archaea are poorly understood, inverted vesicle membranes have been described ${ }^{44}$ This is in agreement with our observations, since the intracytoplasmic vacuoles seemed to be derived from invagination of the external enveloping membrane. Close associations between archaea and chlamydial or mycoplasmal bodies were frequently found. Myxoid matrix (MM) is a collagen alteration usually present in vulnerable plaques and a fundamental lesion of many other diseases with still unknown etiologies, such as prolapse valvar, aortic dissection, and arterial aneurysms. A significant association of archaeal-like elements containing large clear intracytoplasmic vacuoles with MM regions suggests a cause-effect relationship. We speculate that archaea may favor the survival and proliferation of chlamydia and mycoplasma at the vulnerable atherosclerotic plaques since archaea possess superoxide dismutases that would protect them from intra- and extracellular oxidative stress..$^{28}$ In addition to the significant correlation between archaeal organisms and quantity of MM regions in the plaque, archaea correlated with the number of mycoplasmal bodies. Metalloproteinases have been found in association with mycoplasmal infection, ${ }^{45}$ are present in archaea ${ }^{46}$ and they are increased in valvar and aortic MM lesions. ${ }^{47}$ Foam cells, another characteristic of vulnerable plaque, correlated with numbers of chlamydial bodies. These findings favor our hypothesis that archaea may be an important cofactor for the pathogenesis of plaque vulnerability, inducing proliferation of other microorganisms, which may favor the development of myxoid matrix lesions.

\section{CONCLUSION}

This pioneering description of archaeal elements in atherosclerotic lesions indicates that archaea may be a pathogenic organism involved in the pathogenesis of plaque vulnerability by favoring development of ROS and survival of aerobic microorganisms such as mycoplasma and chlamydia. This finding opens new directions for the comprehension of infection in the pathogenesis of atherosclerosis and myxoid matrix degeneration. 
Higuchi ML, Santos MH, Roggério A, Kawakami JT, Bezerra HG, Canzian M. Um papel para organismos de arqueia no desenvolvimento de placas ateroscleróticas vulneráveis e matriz mixomatosa. CLINICS. 2006;61(5):473-8.

PROPOSTA: Placas vulneráveis são caracterizadas por matriz mixomatosa, centro lipídico necrótico, espécies reativas de oxigênio e alto níveis de microorganismos. Micróbios aeróbicos como Chlamydophila pneumoniae e Mycoplasma pneumoniae usualmente não sobrevivem em meio de estresse oxidativo. Arquéias são microorganismos anaeróbicos com poderosas enzimas anti-oxidantes que permitem detoxificação de radicais livres e a presença delas poderia favorecer a sobrevivência de micróbios aeróbicos. Pesquisamos por elementos de arquéia em placas vulneráveis e sua possível associação com degeneração mixomatosa da matriz e aumento do número de clamídias e micoplasmas.

MÉTODOS: Vinte e nove amostras de 13 produtos de aterotomia de lesões grandes e excêntricas de óstio ou bifurcação de coronárias foram estudadas pela microscopia óptica e eletrônica. Agentes compatíveis com arquéia, clamídia e micoplasma foram semiquantificados pela microscopia eletrônica e correlacionados com quantidade de tecido fibromuscular, matriz mixomatosa e células xantomatosas. Seis casos foram também submetidos à reação em cadeia da polimerase com oligonucleotídeos de arquéia.

RESULTADOS: Os 13 casos foram positivos para estruturas sugestivas de arquéia, micoplasma ou clamídia, em pelo menos uma amostra. Houve correlação positiva entre intensidade de matriz mixomatosa versus arquéia $(\mathrm{r}=0.44$, $\mathrm{p}=0.02)$; arquéia versus micoplasma $(\mathrm{r}=0.41, \mathrm{p}=0.03)$ e clamídia versus células xantomatosas $\mathrm{r}=0,42 ; 0.03)$. PCR foi positiva para DNA de arqueia em 4 dos 6 fragmentos. DISCUSSÃO: DNA e formas compatíveis com arquéia estão presentes em placas vulneráveis e podem ter papel fundamental na proliferação de micoplasma e clamídia. Este parece ser o primeiro relato de arquéia aparentemente patogênica em lesões de órgãos internos humanos.

UNITERMOS: Arquéia. Aterosclerose. Matriz mixomatosa. Clamídia. Micoplasma.

\section{REFERENCES}

1. van der Wal AC, Becker AE, van der Loos CM, Tigges AJ, Das PK. Fibrous and lipid-rich atherosclerotic plaques are part of interchangeable morphologies related to inflammation: a concept. Coron Artery Dis. 1994;5:463-9.

2. Steinberg D. Antioxidants and atherosclerosis. A current assessment. Circulation. 1991;84:1420-5.

3. Fuster V, Gotto AM, Libby P, Loscalzo J, McGill H. Task Force 1. Pathogenesis of coronary disease: The biologic role of risk factors. J Am Coll Cardiol. 1996;27:964-76.

4. Fuster V, Badimon J, Chesebro JH, Fallon JT. Plaque rupture, thrombosis, and therapeutic implications. Haemostasis. 1996;26:269-84.

5. Steinberg D, Parhasarathy S, Carew TE, Khoo JC, Witztum JL. Beyond cholesterol. Modifications of low-density lipoprotein that increase its atherogenicity. N Engl J Med. 1989;320:915-24.

6. Simionescu M, Simionescu N. Proatherosclerotic events: pathobiochemical changes occurring in the arterial wall before monocyte migration. FASEB J. 1993;7:1359-66.

7. Vijayagopal P, Srinivasan SR, Radhakrishnamurthy B, Berenson GS Lipoprotein-proteoglycan complexes from atherosclerotic lesions promote cholesteryl ester accumulation in human monocytes/ macrophages. Arterioscler Thromb. 1992;12:237-49.

8. Goldstein JL, Ho YK, Basu SK, Brown MS. Binding site on macrophages that mediates uptake and degradation of acetylated low density lipoprotein, producing massive cholesterol deposition. Proc Natl Acad Sci USA. 1979;76:333-7.
9. Henriksen T, Mahoney EM, Steinberg D. Enhanced macrophage degradation of low density lipoprotein previously incubated with cultured endothelial cells: recognition by receptors for acetylated low density lipoproteins. Proc Natl Acad Sci USA. 1981;78:6499-503.

10. Stocker R, Keaney JF Jr. Role of oxidative modifications in atherosclerosis. Physiol Rev. 2004;84:1381-478.

11. Shor A, Phillips JI. Chlamydia pneumoniae and atherosclerosis. JAMA. 1999;282:2071-3

12. Gupta S. Chronic infection in the aetiology of atherosclerosis-focus on Chlamydia pneumoniae. Atherosclerosis. 1999;143:1-6.

13. Ott SJ, El Mokhtari NE, Musfeldt M, Hellmig S, Freitag S, Rehman A, et al. Detection of diverse bacterial signatures in atherosclerotic lesions of patients with coronary heart disease. Circulation. 2006;113:929-37.

14. O'Connor S, Taylor C, Campbell LA, Epstein S, Libby P. Potential infectious etiologies of atherosclerosis: a multifactorial perspective. Emerg Infect Dis. 2001;7:780-8.

15. Mahony JB, Coombes BK. Chlamydia pneumoniae and atherosclerosis: does the evidence support a causal or contributory role? FEMS Microbiol Lett. 2001;197:1-9.

16. Katz JT, Shannon RP. Bacteria and coronary atheroma: more fingerprints but no smoking gun. Circulation. 2006;113:920-2.

17. Shah PK. Chronic infections and atherosclerosis/thrombosis. Curr Atheroscler Rep. 2002;4:113-9. 
18. Higuchi ML, Sambiase N, Palomino S, Gutierrez P, Demarchi LM, Aiello VD, et al. Detection of Mycoplasma pneumoniae and Chlamydia pneumoniae in ruptured atherosclerotic plaques. Braz J Med Biol Res. 2000; 33:1023-6.

19. Higuchi ML, Ramires JAF. Infectious agents in coronary atheromas: a possible role in the pathogenesis of plaque rupture and acute myocardial infarction. Rev Inst Med Trop S.Paulo. 2002;44:217-24.

20. Santos MHH, Pierri H, Higuchi ML, Nussbacher A, Palomino S, Sambiase NV, et al. Chlamydia pneumonie e Mycoplasma pneumoniae nos nódulos de calcificação da estenose da valva aórtica. Arq Bras Cardiol. 2005;84:443-8.

21. Higuchi ML, Santos MHH, Pierri H, Palomino S, Sambiase NV, Ramires JAF, et al. Mycoplasma pneumoniae and Chlamydia pneumoniae in calcified nodules of aortic stenotic valves. Rev Inst Med Trop S.Paulo. 2002;44:209-12.

22. Nicolson GL, Gan R, Haier J. Multiple co-infections (Mycoplasma, Chlamydia, human herpes vírus-6) in blood of chronic fatigue syndrome patients: association with signs and symptoms. APMIS. 2003;111:55766.

23. Momiyama Y, Ohmori R, Taniguchi H, Nakamura H, Ohsuzu F. Association of Mycoplasma pneumoniae infection with coronary artery disease and its interaction with chlamydial infection. Atherosclerosis. 2004;176:139-44.

24. Kalayoglu MV, Hoerneman B, LaVerda D, Morrison SG, Morrison RP, Byrne GI. Cellular oxidaion of low-density lipoprotein by Chlamydia pneumoniae. J Infect Dis. 1999;180:780-90.

25. Higuchi ML, Castelli JB, Aiello VD, Palomino S, Reis MM, Sambiase $\mathrm{NV}$, et al. Great amount of $C$. pneumoniae in ruptured plaque vessel segments at autopsy. Arq Bras Cardiol. 2000; 74:149-51.

26. Sies H. What is oxidative stress? In: Oxidative stress and vascular disease. Boston: Keaney JF Jr. Boston Kluwer Academic; 2000. p.1-8.

27. Imlay JA. Pathways of oxidative damage. Annu Rev Microbiol. 2003:57:395-418.

28. Cannio R, Florentino G, Morana A, Ossi M, Bartolucci S. Oxygen: friend or foe? Archaeal superoxide dismutases in the protection of intra- and extracellular oxidative stress. Front Biosci. 2000;5:D768-79.

29. Woese CR, Kandler O, Wheelis ML. Towards a natural system of organisms: proposal for the domains Archaea, Bacteria, and Eucarya. Proc Natl Acad Sci USA. 1990;87:4576-9.

30. Lovley DR, Holmes DE, Nevin KP. Dissimilatory Fe(III) and Mn (IV) reduction. Adv Microb Physiol. 2004;49:219-86.

31. Kurtz DM Jr. Microbial detoxification of superoxide: the non-heme iron reductive paradigm for combating oxidative stress. Acc Chem Res. 2004:37:902-8

32. Benvenuti LA, Onishi RY, Gutierrez PS, Higuchi ML. Different patterns of atherosclerotic remodeling in the thoracic and abdominal aorta. Clinics. 2005;60:355-60.
33. Higuchi ML, Sambiase NV, Gois JM, Ramires JAF. Aproximación a una nueva comprensión de la arteriosclerosis: Infecciones asociadas con Chlamydia y Mycoplasma y baja inmunidad. Rev Arg Cir Cardiovas. 2004;2:156-63.

34. Barns SM, Delwiche CF, Palmer JD, Pace NR. Perspectives on archaeal diversity, thermophily and monophyly from environmental rRNA sequences. Proc Natl Acad Sci USA. 1996;93:9188-93.

35. Eckburg PB, Lepp PW, Relman DA. Archaea and their potential role in human disease. Infect Immun. 2003;71:591-6.

36. Reeve JN. Archaebacteria then... Archaes now (are there really no archaeal pathogens?). J Bacteriol. 1999;181:3613-7.

37. Cavicchioli R, Curmi PM, Saunders N, Thomas T. Pathogenic archaea: do they exist? Bioessays. 2003;25:1119-28.

38. Florin TH, Zhu G, Kirk KM, Martin NG. Shared and unique environmental factors determine the ecology of methanogens in humans and rats. Am J Gastroenterol. 2000;95:2872-9.

39. Srinivasan V, Morowitz HJ. Ancient genes in contemporary persistent microbial pathogens. Biol Bull. 2006;210:1-9.

40. Vianna ME, Conrads G, Gomes BP, Horz HP. Identification and quantification of archaea involved in primary endodontic infections. $\mathrm{J}$ Clin Microbiol. 2006;44:1274-82.

41. Rachel R, Wyschkony I, Riehl S, Huber H. The ultrastructure of Ignicoccus: evidence for a novel outer membrane and for intracellular vesicle budding in an archaeon. Archaea. 2002;1:9-18

42. Peretó J, López-Garcia P, Moreira D. Ancestral lipid biosynthesis and early membrane evolution. Trends Biochem Sci. 2004;29:469-77.

43. Howland JL. Archaeal portraits. In: The surprising archaea. Discovering another domain of life. New York: Oxford University press; 2000. p.79.

44. Ring G, Eichler J. Characterization of inverted membrane vesicles from the halophilic archaeon Haloferax volcanii. J Membr Biol. 2001;183:195-204.

45. Simonen-Jokinen TL, Eskelinen UM, Hartel HM, Nikunen SK, Saloniemi HS, Maisi PS. Gelatinolytic matrix metalloproteinases-2 and -9 in tracheobronchial lavage fluid obtained from calves with concurrent infections of Pasteurella multocida and Mycoplasma bovirhinis. Am J Vet Res. 2005;66:2101-6.

46. Dias-Perales A, Quesada V, Peinado JR, Ugalde AP, Alvarez MF, GomisRüth FX, et al. Identification and characterization of human archaemetzincin-1 and-2, towo novel members of a family of metalloproteases widely distributed in archaea. J Biol Chem. 2005;280:30367-75.

47. Segura AM, Luna RE, Horiba K, Stetler-Stevenson WG, McAllister HA $\mathrm{Jr}$, Willerson JT, et al. Immunohistochemistry of matrix metalloproteinases and their inhibitors in thoracic aortic aneurysms and aortic valves of patients with Marfan's syndrome. Circulation. 1998;98(19 Suppl):II331-7. 